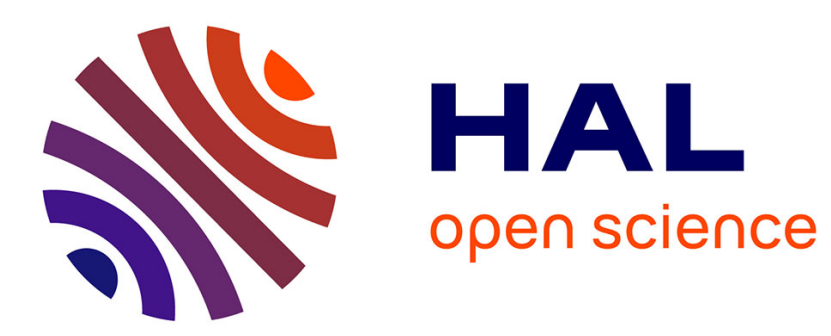

\title{
Why evolution has to matter to cognitive psychology and to philosophy of mind \\ Joëlle Proust
}

\section{To cite this version:}

Joëlle Proust. Why evolution has to matter to cognitive psychology and to philosophy of mind. Biological Theory, 2007, 2, pp.0-00. ijn_00139330

\section{HAL Id: ijn_00139330 \\ https://hal.science/ijn_00139330}

Submitted on 30 Mar 2007

HAL is a multi-disciplinary open access archive for the deposit and dissemination of scientific research documents, whether they are published or not. The documents may come from teaching and research institutions in France or abroad, or from public or private research centers.
L'archive ouverte pluridisciplinaire HAL, est destinée au dépôt et à la diffusion de documents scientifiques de niveau recherche, publiés ou non, émanant des établissements d'enseignement et de recherche français ou étrangers, des laboratoires publics ou privés. 
Why evolution has to matter to cognitive psychology and to philosophy of mind

Joëlle Proust

CNRS

Philosophy of mind has essentially been shaped by philosophers of language, epistemologists and philosophers of science, such as Hilary Putnam, Donald Davidson, John Searle, Jerry Fodor and Fred Drestke. Much valuable work has been done in their wake, in the logical, semantic and pragmatic analysis of belief-desire attribution, in the theory of intentionality and in the analysis of meaning as well as in the exploration of the mental content involved in all kinds of propositional attitudes (perception, memory, emotion, etc.).

This line of research permeated various other domains in cognitive science, such as the development of mentalisation, the psychology of action and of reasoning, psycholinguistics, cognitive anthropology and A.I. Growing suspicions were raised however that an exclusively language-oriented view of the mind, focussing on the characterization of anhistorical, static mental states through their propositional contents, was hardly compatible with what is currently known of brain architecture and did not fare well when confronted with results from many behavioral studies of mental functions. My aim in what follows is to show that these forms of dissatisfaction stem from the fact that brain evolution and development were either entirely ignored, or insufficiently taken into account in inquiries about the structure of mental contents. I will discuss how evolutionary and developmental approaches to human cognition are now in a position to substantially alter the central paradigms currently used in cognitive science.

\section{Teleosemantics}

Ruth Millikan (in Millikan, 1984) was the first philosopher who recognized that no satisfactory account of intentionality, (ie: of the meaning or representational value of mental states) can be provided without taking into account that these states are the result of a Darwinian selection process.

Mainstream views on intentionality rely on causal accounts: the representational contents of beliefs coincide with the external conditions that cause them. For example, a certain representation is of a cow because it is a cow that produced this representation. There are several problems with this view: it fails to explain the capacity of representations to misrepresent, to represent non-existent entities, and to represent only certain aspects of the object with which the organism is interacting causally.

Ruth Millikan reoriented our way of thinking about these questions by invoking biological concepts. Her idea was that representational function can only be understood as the result of an evolutionary process through which certain mappings are being selected by virtue of their causal effects on their bearers' reproductive capacity. In this view, minds exist- as a set of mental functions - because having these capacities and the various dispositions they include has modulated (in the 
past) the reproductive success of the entities that has them. For example, a certain visual pattern is categorized as a rabbit because that visual pattern has acquired the function to trigger the belief that there is a rabbit only when a rabbit rather than, say, a snake, is present. The normativity inherent to function, Millikan claimed, was in a better position to explain misrepresentation and aspectuality than the causalist account.

\section{Cognitive functions as dynamic systems}

Given the promise of this approach, why did teleosemantics (and, more generally, the biological approach to mind) fail to become a standard philosophical and psychological method to analyse mental function ? Furthermore, why are teleological analyses so sparse in areas beyond belief formation, for example in learning, emoting and acting $?^{1}$ These domains obviously involve purpose, motivation, and adaptive context, which make teleological considerations crucial. Here is one possible explanation : these domains reveal a fact about cognitive adaptation that a disposition such as belief might mask: mental "states" are not static; they are dynamic entities whose function is to adapt to a changing environment. In my view, a cognitive scientist or a philosopher who recognize the dynamic character of the cognitive responses to selective pressures, ar facing two difficulties.

The first is that teleosemantics in its Millikanian version is ignoring the biophysical and informational constraints in which cognition had to evolve. ${ }^{2}$ Just as understanding posture and gait in terrestrial organisms presupposes understanding the physical constraints with which an optimally functioning system has to comply ( a certain algorithm reflecting in which limits bodily mass, acceleration, velocity, bone length, etc. can vary, given a specific physical and biological environment), understanding the evolution of learning presupposes understanding the kind of constraints that apply to information-processing systems. There are two things to consider in this respect. First, information is present in nature and up for grabs; in Dretske's account, ${ }^{3}$ it is the converse of a regular causal relation between two physical events; extracting this relation allows recruiting an event as a way to represent another. Second, information is crucially relevant to survival. This leads to suppose that specific pressures for representing certain facts might explain brain architecture in each species. In addition, one might hypothesize that the very format in which information is stored and retrieved plausibly reflects the conditions in which information was initially extracted in phylogeny. As long as biological causality is taken to be irreducible to physical causality, these questions cannot be posed, much less addressed. ${ }^{4}$

The second difficulty is that even when the importance of information for survival is recognized, there is at present no established paradigm of how dynamical capture and storage of information should be modeled; a computational representation of dynamic entities is a topic for current research, not a textbook set of

\footnotetext{
1 There are some exceptions: In philosophy, see Sterelny, (2003), Papineau (2003), De Sousa (2000, 2004 ), Proust (2005). In psychology, see in particular Prinz (1987 \& 1990). In cognitive anthropology, see Sperber (2000), and Orrigi \& Sperber, (2000).

${ }^{2}$ See Millikan (1993).

${ }^{3}$ See Dretske (1981 \& 1988).

${ }^{4}$ For a defense of this claim, see Proust (1997).
} 
universally recognized methods. As many analysts of cognitive science recognize, ${ }^{5}$ taking a dynamic-selectionist view of the mental in a computationally oriented science of the mind is one of the major challenges for the years to come. One interesting line of research is the mathematical modeling approach adopted in dynamic systems theories (specifically "Artificial Life"). The idea behind this approach is that the evolution of a system over time depends crucially on the evolution of the other systems with which it is interacting. The complex dynamic situation generated by the coupling of the co-evolving systems can only be captured by new mathematical tools, like dynamic systems theory, and viability theory; they aim to discover invariants in the co-evoluting systems' behaviors. These tools are only starting to become available. The question remains how these invariants can be used towards an informational-representational account of mental function.

Dynamical models will only be useful if they are applied at the right kind of level, which requires a tight interaction between mathematicians, biologists and cognitive neuroscientists. Here evolutionary biology might have a crucial role to play in determining the format in which information is stored and retrieved in the primate brain ; comparative biology also seems to be in a position to offer a major contribution to this endeavor.

\section{Embodied cognition}

An indication that cognitive scientists are now coming to realize the importance of both issues - the biophysical constraints in which cognition is evolving and the dynamical format in which information is extracted - lies in the fact that a new approach to cognition is currently gaining currency. Called "Embodied cognition", it advances the view that one cannot understand cognition without considering how the organism as a whole (including its body and its associated sensorimotor capacities) is interacting with its environment. Indeed it is a consequence of a teleological view of the mind that cognitive operations have been selected on a background of existing adaptations and of stable features in the external world.

Such a view was already implicit in the foundational role that Wolfgang Prinz and his group ${ }^{6}$ attributed to the ideomotor principle in Experimental Psychology. This principle states that perception and action are not isolated mental functions; they are operate jointly and can be shown to share a common representational code. Another early attempt at recognizing the role of distal elements in cognition was made by the proponents of cognitive situatedness in social science. Echoing the biologists' concerns, these socials scientists insisted that the physical and social context play a central role in the development and functioning of the mind. ${ }^{7}$ Some proponents of this view endorsed a more radical claim, inspired by Gibson's ecological theory of perception: representations play no role in cognition, because the information is directly made available to the system by its interaction with the environment. This radical claim however leaves us in the dark as to how such an interaction is possible - how are "know-hows" being acquired and updated if no information is stored in memory ${ }^{8}$

\footnotetext{
${ }^{5}$ See for example Clark (2000).

${ }^{6}$ See inter alia Prinz (1987) and (1990).

${ }^{7}$ Cf. Lucy Suchman, (1987), whose work influenced research in "embodied robotics".

${ }^{8}$ See Clark (1999) for a discussion of the anti- representationalist stance of "radical embodiment" proponents.
} 
Not suprisingly, researchers in embodied cognition favor dynamical models : a mind predicts how successful an action will be by reenacting covertly previous performances of the same type; representations thus must be dynamic entities. But how can we analyse them ? Larry Barsalou's (2005) work on abstract thinking is particulary revealing of the tension between the requirements of dynamic modeling and the need for a representational account of mental functions; he suggests that what he calls perceptual symbol systems, i.e. the combination of simulatory perceptual sequences based on the subject's earlier encounters with the relevant experience, underlie the capacity to conceptualize, to reason, and to abstract new knowledge from previously acquired knowledge Abstractions, in his view, are not stored in memory, but constructed online and then discarded. Unconscious as well as conscious reenactments might therefore underlie memory, conceptualization, text comprehension and reasoning.

These new emergent models are all motivated by the view that biology might offer revolutionary insights into mental function. Given the observations above, old questions, such as " what is information ?" can only be adequately adressed by physicists and mathematicians in collaboration with neurobiologists and evolutionary biologists. New ones will soon have to be raised as well ; for instance, should we retain the traditional picture of the mind neatly divided into "faculties", such as perception, action, reason, and imagination ? Or will the embodied cognition research suggest other ways of carving up mental functions ? Here too evolutionary biology will also have a major contribution to offer.

\section{References}

Barsalou, L.W., (2005). Abstraction as dynamic interpretation in Perceptual Symbol Systems, in L. Gershokoff-Stowe \& D. Rakison (eds.), Building object categories, Majwah, NJ.: Erlbaum, 389-431

Clark, A., (1999), An embodied cognitive science ? Trends in cognitive Science, 3,9, 345-351.

Millikan, R. (1984). Language, Thought and other biological categories, New Foundations for Realism, Cambridge, MIT Press.

Millikan, R. (1993). Explanation in Biopsychology, in J. Heil \& A. Mele, (dirs.), Mental Causation, Oxford, Clarendon Press, 211-232

Origgi, G. \& Sperber, D. Evolution, communication, and the proper function of language, in Peter Carruthers and Andrew Chamberlain (eds.), Evolution and the Human Mind: Language, Modularity and Social Cognition. Cambridge: Cambridge University Press.

Papineau, D. (2003). The Roots of Reason, Philosophical Essays on Rationality, Evolution, and Probability, Oxford: Oxford University Press.

Prinz, W..1987. Ideo-motor action, in H. Heuer \& A.F. Sanders .(eds.) Perspectives on Perception and Action, Lawrence Erlbaum, 47- 76.

Prinz, W..1990. A common coding approach to Perception and Action, in $\mathrm{O}$. Neumann \& W. Prinz (eds.) Relationships between Perception and Action, Berlin: Springer-Verlag, 167-201.

Proust, J. (1997) Comment l'esprit vient aux bêtes, Paris: Gallimard.

Proust, J. (2005a): La nature de la volonté, Paris: Gallimard. 
Proust, J.(2005b), Rationality and metacognition in non-human animals, in S. Hurley \& M. Nudds .(eds.) Rational Animals ?, Oxford, Oxford University Press.

Sousa, R. (de). (2000), Learning to be Natural in Neil Roughley, (ed.), Being Humans, New York \& Berlin: De Gruyter (2000) pp. 287-307.

Sousa, R. (de). (2004). Evolution et rationalité, Paris: Presses Universitaires de France.

Sperber, D. (2000). Metarepresentations in an evolutionary perspective, in Dan Sperber ed. Metarepresentations: A Multidisciplinary Perspective. Oxford: Oxford University Press, 2000, pp.117-137.

Sterelny, K. (2001). The Evolution of agency and other essays, Cambridge: Cambridge University Press.

Sterelny, K. (2003). Thought in a Hostile World, The evolution of Human Cognition, Oxford: Blackwell.

Suchman, L. (1987). Plans and Situated Actions: the problem of human-machine communication.Cambridge: Cambridge University Press. 